\title{
Sonic monstrosity
}

Isabella van Elferen, Kingston University London

\begin{abstract}
This article explores the sonic dimension of monstrosity, charting the sounds that monsters make as well as the sounds that announce monsters. Basing on examples from a range of media from literature to cinema, television and video games, the article argues that sound and especially music are capable of reflecting the monster's most unrepresentable characteristic: its dorsality.
\end{abstract}

\section{Keywords}

sound

film music

television music

video game music

horror

monsters

Nosferatu - tönt dies Wort dich nicht an wie der mitternächtige Ruf eines

Totenvogels $?^{1}$

In the survival horror video game Silent Hill: Shattered Memories, protagonist Harry Mason wakes up from a car crash near the village of Silent Hill. It is a pitch black night, it is snowing, and Harry's daughter Cheryl has disappeared. As he sets out to find her, the whirl of snowflakes, the labyrinthine surroundings, the darkness and the fog blur Harry's as well as the 
game player's perception. The eerie claustrophobic feel of the game play, which offers no real clues to Cheryl's whereabouts, is underlined by the continuous visual references to Gothic and horror cinema ranging from The Shining (Kubrick, 1980) and Psycho (Hitchcock, 1960) to Twin Peaks (Frost and Lynch, 1990-1991) and House of Leaves (M. Z. Danielewski, 2001). Turning the uncanniness of terror into the explicitness of horror, the town sometimes suddenly freezes over. In these 'nightmare' sequences corpses become visible under the blue ice, and malevolent zombie-ish monsters appear from everywhere to attack Harry. The unnerving soundtrack that Akira Yamaoka created for Silent Hill offers little relief. The diegetic soundscape is uncannily silent. Only Harry's echoing footsteps, his breathing, and the radio static on his mobile phone - which functions as a ghostly antenna - can be heard. In the nightmare sequences these sounds are accompanied by a barely perceivable nondiegetic soundtrack. Within an ambient mixture of looped nonlinear motifs and suffocating white noise, pounding drones announce both the presence and the ill intentions of the horrid zombie monsters. The noise, unpleasant as it is, becomes Harry's (and the player's) only navigational clue as the monsters' approach can be heard before they can be seen. When played with a headset or surround sound, they can be quite precisely located. In Silent Hill, you listen for your life.

Monstrosity, that goes to show, is a noisy business. This article aims to open your ears to monstrous sounds and sonic monsters.

Monsters represent the embodied horror of Otherness, of deviance, of excess. Their obscene hyper-visibility allows the projection of cultural as well as personal fear-desires onto their monstrous bodies. Monsters, Fred Botting argues, 'give form to fears, desires and anxieties, allowing the channelling and expulsion of emotional energies' (2003: 341). Monsters do not 
exist except in our own horrified-exhilarated imagination: they appear within fictional contexts only, their perfectly grotesque appearance carefully construed from scraps and fragments of textual and visual signifiers. Pointing with the painful precision of perverse imagination, the monster's job is to signify. To do so explicitly, abjectly, and causing the horror that we long to console ourselves with.

But what was that noise?

\section{'Did you hear that?' Noisy monsters}

The sounds of the monster indicate that it is alive, an embodied reality rather than an imagined danger. The reader of Mary Shelley's Frankenstein, to begin with one of the Urmonsters of Gothic fiction, can be sure that the monster is alive when he makes sounds: 'His jaws opened, and he muttered some inarticulate sounds, while a grin wrinkled his cheeks' (1985: 52). The timbre of these monsters' voices, must be indicative of their grotesqueness, their abjection: it may sound like a sickening GROWL! or, conversely, ring with childelíke. ímฉосељсе. The horror film cliché of monstrosity speaking or singing with the children's voice of innocence was taken to another level in the television series Torchwood: Children of Earth (2009). In this five-episode television drama, alien monsters speak with the mouths of all the children of the world. In unnerving, repeated unison, millions of children's voices state that 'We. Are. Coming'.

Frankenstein (1985) and other classics of Gothic literature became the classics of horror cinema in early sound film. 'Talkies' provided enabled movie audiences to perceive the sounds of cinematic monsters as well as those of the monster that was film technology. In its early history, the audio-visual cinema experience proved a double fascination as well as a double dread, for even though the realism of talkies strengthened film immersion it was 
machines talking, projected phantoms speaking. These sounds created an inevitable cognitive dissonance in audiences, as we naturally assume sounds, and especially voices, to have a locatable source. The bodiless voices of early cinema, however, seemed to have no origin. Movie audiences were faced with the uneasy realization that their physical source lies beyond the perceivable, in 'phantom bodies' (Chion 1994: 126-28). The separation of sound from its origin, which is the cause for such supernatural evaluations of recording technology, has been termed schizophonia by soundscape theorist R. Murray Schafer (1994: 90-91). Schizophonic sound suggests invisible presences and makes the film viewer look over her shoulder to check what is behind her: just like these sounds that are 'neither inside nor outside the image' suggest (Chion 1994: 129), diegesis and nondiegesis might just have started to overlap unnoticedly, and the intangible entities producing them might just be occupying the next chair in the darkened cinema space.

The uncanny effect of talking film is one of the main attractions of Tod Browning's 1931 Dracula, which otherwise has received enduring criticisms for its artificiality, Lugosi's overacting, and the narrative thinning out of Stoker's book. A thick Hungarian accent, a bombastic voice, and canned sound quality have made the phrase 'I ahm Drrahkuhlah' quite as immortal as the Count himself is supposed to be. This is undead speech by all means, and the strangeness of Lugosi's accent and vocal timbre only highlight the very fact that is most disturbing about this scene: it speaks. The Gothic monster that is Dracula here symbolizes the Gothic monster that is schizophonic sound film, the hubris of the undead vampire being a perfect metaphor for that of the lifeless machine showing unnatural humanity in speech. At least James Whale's version of Frankenstein's monster (1931) doesn't speak - very unlike the eloquent monster in Shelley's book it just grunts, growls and howls, like a beast should do. This monster is sonically introduced in an even less human way than Dracula. The scene in which he comes to life is overfilled with sounds: a heavy storm roars and thunders outside as 
Frankenstein's machines start sizzling, crackling and thumping, and as the mysterious life powers attributed to electricity are being transmitted onto the Golem. The sound in this scene is very loud even to twenty-first-century standards, and it will not have failed to impress and frighten early sound film audiences. If Lugosi's Dracula vocally reveals his monstrosity through schizophonic otherness, Karloff's Frankenstein does so through excess. In Mamoulian's Dr Jekyll and Mr Hyde (1932) the distinction between human and monster is much less clear, and the transformation from Jekyll to Hyde is established sonically through a curious combination of human and technological sounds. Mamoulian recorded the sound of Fredric March's heartbeat, which accompanies the transition throughout; as Jekyll passes out and starts to hallucinate, a high-pitched metallic sound overlays the heartbeat and circular camera movements indicate that the room starts to spin. At the end of the transition, the metallic sounds stop before the heartbeats give way to silence as the camera turns to the mirror and the scientist sees himself as Hyde, the monster. The recorded heartbeat works like an extreme close-up, moving the viewer straight into the disturbing intimacy of the transformation - Jekyll/Hyde's body. At the same time the schizophonic nature of this recorded sound disrupts the direct physical relation between the sound and its origin, literary tears the heart and thereby the humanity out of Dr Jekyll. The metallic noise, machine-made and non-musical as it is, confirms the difference between the human Jekyll and his doppelganger, the degenerate beast Hyde.

If sound can prove that monsters are alive, it also that it might be closer to you than you'd like it to be. Precisely because of the fact that we assume sound to be embodied it is also an important marker of location. Sounds indicates that a monster is near, like it does in Silent Hill's sonic GPS. In Japanese horror film Ju-On (Shimizu, 2003) and its Hollywood remake The Grudge (Shimizu, 2004) monstrous presence is indicated by sighs and grunts, but most emphatically by the neck hair-raising death rattle of long-haired ghost Kayako. This 
terrifying sound, which continues to haunt the viewer of $J u$-On/The Grudge long after the film has been watched, has become the sonic brand of the films.

The ghostly effect caused by schizophonic film sound lends itself readily to the representation of monstrous vicinity. The echoes, voices and sighs described in ghost stories can acquire an audible presence while they remain hidden from sight, and appear to emerge from the uncontrollable space beyond the screen - the disembodied whispers in the jungle that announce the smoke monster in television series Lost(2004-10) are an almost tangible example. These fleeting sounds and their imagined bodies cannot represent anything but the 'recognition and celebration' of our own fears and desires, our own monstrosities (Halberstam 1995: 27); because it gives voices to invisible presences it evokes the return of the very deeply repressed.

When monsters do not only make sound but also music, they seem to be able to have emotions and therefore be more human than fits the comfort zone. As musicality is perceived to be a human quality only, musical monsters are arguably even more terrifying than nonmusical ones, just like the speaking monster is more frightening than the growling one. The vampires in Tony Scott's 1983 cult movie The Hunger play the cello and the harpsichord, and this makes them all-too human, cultured, and attractive. Janet Halfyard argues that the diegetic music in The Hunger taps into a very specific monstrous projection, that produced by American ideas about European otherness:

one should never trust anyone in a Hollywood film who is a performer of classical music, as this tends to be elided with European identity and then positioned as being threatening - morally or physically - to American characters and their values.

(Halfyard in Hayward 2009: 172) 
The lethal infatuation of an American doctor Sarah Roberts (Susan Sarandon) for these wildly attractive but untrustworthy European vampires (played by wildly attractive European actors Catherine Deneuve and David Bowie) supports this theory. The same trope is picked up, among many other examples, in Neil Jordan's Interview with the Vampire (1994), in which the monster Lestat learns the child vampire Claudia to play the pianoforte. Thankfully, though, Lestat is not really musical, so that his monstrosity remains easily identifiable:

[Lestat] had an immense reach and even in life could have been a fine pianist. But he played without feeling; he was always outside the music, drawing it out of the piano as if by magic, by the virtuosity of his vampire senses and control; the music did not come through him, was not drawn through him by himself. (Rice 2006: 143)

Monstrous musicality can make monsters uncannily like ourselves rather than comfortably Other. As such the musical humanness of monsters is a classical figure of the Freudian uncanny, the making-familiar of the unfamiliar, the bestowal of human qualities onto what should by all means be inhuman. When monsters play music they often find a way to play your consciousness too: is the beast really all that bad if it can play that beautifully? Claudia may be a blood-sucking predator, but she plays so sweetly [...] Besides the thin line between monstrous otherness and recognizable humanness, the musical talents of monsters can also reveal the blurry boundaries between human capacities, superhuman capacities and their monstrous side-effects. The trope of the diabolical organist, which pervades horror cinema, plays not so much on the humanness of the monster but on the monstrosity of the human: it emphasizes the ease with which the superior genius of masters such as John Sebastian Bach can tip over into grotesque and possibly evil abjection. 


\section{Hark, 'tis here! Monstrous soundtracks}

While many monsters are noisy or musical themselves, sound and music are also used to communicate monstrosity to listeners over the monsters' heads. Accompanying monstrous narratives in film, television or video games, and audible only to their viewers and players, nondiegetic soundtracks convey extra interpretative tools complementing the information provided by the visual or textual narratives. ${ }^{2}$ In order to serve as auditive indicators of monstrosity, nondiegetic soundtracks require certain qualities: they need to offer contrast, musical otherness, excess and dorsality. I will discuss these one by one.

Reflecting the deviation that characterizes monsters, the sounds and music indicating them always provide a clear contrast with their sonic surroundings. A soundtrack may be unexpectedly s i 1 e n t or Suddenly Loud when a monster is near: the horror conventions of the uncanny silence when the hero of a film enters a danger zone, and, conversely, the sudden blast of loud dissonance (called stinger in film music theory) sounding when the murderer appears in close-up are typical instances of such monstrous musical contrast.

Monsters need to be sonically as well as visually other, an effect that can be achieved in nondiegetic soundtracks through the use of timbre or composing style. Timbre, the 'grain' of musical sound (Barthes 1977), can be described as musical temperature, colour or light, and is tremendously important for listeners' interpretation of the affective content of music. Certain timbres have almost universally monstrous connotations. The growl and the grunt are as deviant in film and television soundtracks as they are in rock and metal bands; the machinic connotations of electronic or digital white noise are used to indicate Frankensteinian monstrosity from early sound film to horror video games; flageolet tones have an unfailingly eerie and spectral effect, from western blockbusters such as M. Night Shyamalan's The Sixth Sense (1999) (soundtrack by James Newton Howard) to the chilling atmosphere in J-horror films such as $\mathrm{Ju}-\mathrm{On}$. 
A musical marker of otherness that can be more pervasive than single instances of timbre is composing style. Various forms of exoticism and orientalism mark non-western otherness in early nondiegetic composing. The film score, for instance, to Murnau's 1922 Nosferatu: A Symphony of Horror, Hans Erdmann's 'Fantastisch-Romantische Suite', represents prescribed pieces for theatre musicians and contains ten compositions with titles such as 'Ghostly', 'Strange' and 'Grotesque'. When Thomas Hütter (the film's version of Jonathan Harker) enters the Carpathians we hear music that is quite obviously intended to indicate 'Eastern European otherness', with open fifths and single syncopated clarinet or violin melodies.

Musical orientalism and exoticism have meanwhile been replaced by atonality as the most used compositional marker of otherness. Its estrangement from traditional tonal cadencing and grounding functions as a musical representation of things out of the ordinary, deviant, monstrous. Kevin Donnelly has argued that atonality figures in horror films as 'the anti-matter of high art' (2005: 44): in the conventionalized and meaning-laden idiom of film composing it has become and effective signifier of deviance and defiance. In Stanley Kubrick's The Shining, for instance, the foregrounded presence of Béla Bartók’s, György Ligeti’s and Krzysztof Penderecki's atonal music suggests at once the uncanny humanness and the monstrosity of Jack Torrance's demise (cf. Donnelly 2005: 44-51).

In the 1970s and 1980s the atonal signification of otherness became infused with electronic timbres, and further enhanced through digital technology in the 1990s and 2000s. This combination of compositorial means has had a lasting effect on nondiegetic composing. First, electronic and digital sounds are supremely schizophonic, their origin none other than machines that allow not only the separation of sound from its source but also its distortion, delay, or dissolution. Musical machines, moreover, are singing Golems: their timbre connotes the Frankenstein trauma of sentient technology. Finally, the almost infinite range of drones 
and white noises that can be created with the help of technology enables an effective musical expression of transgression and monstrosity: with musical machines, composers can easily surpass the confines of tonality, rhythm and fixed timbres. The accumulation of schizophonic disembodiment, monstrous timbre and musical transgression that characterizes electronic and digital film sound has proved eminently suitable for science fiction, horror and Gothic movies alike: it can express sci-fi fascinations, horror monsters and the twilight zones of technological uncanny. When the aliens in Torchwood: Children of Earth have descended into Londen, their speech is translated through intricate machines, producing an uncannily civilized but distorted British voice. This machinic monstrosity is commented upon by one of the bystanders: 'It hasn't got a mouth. It's got bloody speakers'.

This accumulation is the pervasive means of expression for the soundtrack of John Carpenter's The Fog (1980) (soundtrack by the director). The monster in this movie is a ghost of human origin manifesting itself in a radiant mist. The film stages a typically Gothic return of the repressed, signalled by the an emphasis on ticking clocks (collapse of different timelines) and machinic sound (disembodied presence). These machines emit sounds that could not remotely be understood as human, suggesting an unnatural rather than human origin of the revenants. The fog leitmotif resembles a distorted foghorn made by synthesizers. It consists of an atonal, arhythmical drone that never cadences, never even forms as much as a melody, but only pulses in strong crescendos and glissandos (cf. Donnelly in Lerner 2010: 152-67). The inhuman sound of the fog in the nondiegetic score contrasts sharply with the diegetic soundtrack, the old-fashioned all-American - and obviously tonal, human made music on KAB Antonio Bay, female protagonist Stevie Wayne's radio channel. The radio station, which is located in an old lighthouse and broadcasts sentimental tunes, plays an important role in the plot development. Wayne is able to detect the fog before the rest of the village, and sends out 'live' warnings it in her radio show. The station also serves as an index 
of the underlying, more abstract themes of spectrality and disembodiment. The golden oldies on the radio and Wayne's own taste for baroque music provide musical analogies to the theme of the return of past times. Wayne's voice itself is emphatically used to demonstrate that schizophonic sound evokes the possibility of the reunification of sound and its physical origin. She starts her show with the words 'Stevie Wayne here, beaming a signal across the sea', thus explicating the separation of her voice and her body. A male listener immediately traces the sound back to its imagined sexy source: 'Boy, would I like to meet her'. The contrast with the synthetic monstrosity of the fog-motif could not, it seems, be bigger, but in fact Stevie's sexy schizophonia directs the audience's ears straight towards the schizophonia implicit in those ominous drones: the desire for the female body whose tangible presence is indicated through 'live' radio technology must, in uncanny parallel, reveal the ghostly presence indicated through electronic musical technology. The gruesome demise of those men who comment upon Wayne's sexy voice confirms the absolute untrustworthiness of schizophonic sound. By drawing viewers' attention to the parallel between the two types of disembodied sound The Fog blurs the boundaries between diegesis and nondiegesis as well as those between past and present.

A similar procedure characterizes Gore Verbinski's The Ring (2002) (soundtrack by Hans Zimmer). Here the monster is a human ghost who manifests herself through videotapes and recorders. As in The Fog, the unnatural return of the ghost is sonically represented by machinic sound. In accordance with the visual appearance of the spectre the main sound effects consist of sustained and often crescendo television static. In heavy contrast with the conventional symphonic and tonal score that Zimmer provided, these noises stand out as constant reminders of the looming danger emanating from the mysterious videotape. Digitally produced, atonal noise is an indicator of monstrous presence in this film and placed within a 
continuum from silence-as-absence to noise-as-inhuman-presence to the extremely-loud-andunbearably-close crescendo of the stinger.

The third musical characteristic of monsters is excess: a lot of monstrous nondiegetic music is almost too loud, too harsh, too dissonant, involves quite too many brass and percussion instruments, and goes on so long it verges on the unpleasant. The masters of this type of musical monstrosity can be found in the rich history of the Hammer Studios in London. Between 1957 and 1974, Hammer created 46 movies depicting horror of all varieties: vampires, Franksteinian monsters, mummies, werewolves, zombies, aliens, etc. The Hammer films are direct precursors of the splatter movie, which is equally focused on the hyperbolic presentation of as much blood, guts and scantily clad screaming women as possible. With regard to their soundtracks the studios followed the patterns initiated by Classical Hollywood: the foregrounding of sound as an indicator of monstrosity. The Hammer horror soundtracks have been as influential as the visuals of the films, and many aspects of their style, which included both diegetic and nondiegetic elements, have become the standard for horror film composing.

Like in Classical Hollywood, the otherness of Hammer monsters is indicated diegetically through foreign accents and animal sounds. The diegetic sound in the films is complemented by nondiegetic music, of which the studios made extensive and trend setting use. Given the explicit style of Hammer, its soundtracks needed to be unambiguous also. The use of short musical motifs provides audiences with clear indications of which movie character is good and which evil, and when these respective characters are going to appear. Such motifs are called leitmotifs in film music theory, after the leitmotifs provided in Richard Wagner's operas. Composer James Bernard created a Dracula leitmotif for Terence Fisher's 1958 Dracula that was also used in the various sequels to the movie. The trombone motif consists of a downward octave leap in punctuated rhythm matching the pronunciation of the 
word 'Dracula' (Cf. Hannan in Hayward 2009: 65-69). The leitmotif is introduced in a scene staging explicit danger: when Dracula attacks for the first time the nondiegetic music is much more agitated than the visuals are, which only show Christopher Lee's fake fangs and red eye make-up. It is the accompanying music that enlivens the scene: the trombone motif is repeated in strong crescendo and underlined by timpani beats, building up to a wild climax of dissonant brass chords and gongs. When it is thus established that this is the Bad Guy Music, it becomes a recognizable leitmotif throughout the rest of the film, occurring also when Dracula is not around.

Another type of excessive musical monstrosity occurs in The Vampire Lovers (Baker, 1970), the first of Hammer's notorious Karnstein Trilogy, a set of soft-pornographic lesbian vampire films (very) loosely based on Sheridan LeFanu's 1871 Gothic novel Carmilla which is aptly characterized through its poster taglines, 'Blood Nymphs!' and 'Ghoulish! Gory! Ghastly!'. In the introductory scene to this film chromatic double bass movements accompany the shots of the deserted cemetery. The next shot shows a relaxed pub scene, in which high violin tremolos heard underneath the diegetic sounds indicate that something horrible is going to happen to the drinking ignorami. Piercing shrieks from outside point the way, and the discovery of a dead victim is accompanied by the sudden boost of dissonant brass stingers. The camera pans off to the path to the cemetery, where the vampire creeps away to the sound of low drumbeats. One last shot of bloody fangs re-activates the brass stinger; and the scene is over. This short sequence of very explicit footage and very standard music sets the tone for the rest of the film, and it does so in no uncertain ways. Every single bit of music in his introduction has an unambivalent meaning in the horror soundtrack idiom: the eerie atmosphere created by the bass chromaticism, the foreboding working of the violin tremolos, the disembodied screaming that invites the confirmation of its source, and, of course, the loud and dissonant stingers that make the horror viewer jump from her chair. Hammer's musical 
language is so explicit that it is practically possible to understand this scene without even watching it. This type of musical signification has been referred to in semiotic terms as ancrage, the emphatic linking together of visual and musical material which 'wards off the displeasure of [...] potential ambiguity' (Gorbman 1987: 58-59).

Excessively loud and semiotically over-explicit sound and music can support the visual obscenity of horror. In the cinematic and musical format of the Hammer Studios unsubtle is the keyword as the twilight zones and liminal spaces of Gothic are replaced by the screaming excess of horror. Hammer's stock of musical, visual and audio-visual icons lean so heavily on - leitmotivic and foreboding - ancrage that they become a musical language of horror that can be read as easily as low camera angles and jump cuts. This recognizable, unambiguous musical language is often characterized by excess: the stingers, an effective musical equivalent of splatter, are just that bit too loud and too dissonant, the leitmotifs are repeated too often, and the iconography of tremolos and drum rolls, crescendos and glissandos is as obtrusive and obscene as that of bloody fangs and heaving cleavage. The enormous and repetitive supply of leitmotifs, stingers, and musical forebodings of danger produced by the Hammer composers have been so influential that they have been referred to as 'a musical reference bank for future horror-film composers' (Hannan in Hayward 2009: 71).

The last quality of monstrous sound pertains to what David Wills calls dorsality. The dorsal indicates that which is behind our back, in the darkness, which cannot be seen unless we turn around: that which forces us to reconfigure our cognition of ourselves in relation to the world around us. The dorsal is not perceivable through sight but comes to us through other senses: 'sometimes through $[\ldots]$ smell, $[\ldots]$ but more likely through hearing, announcing itself in a whisper or a shout, in a rumble or a murmur' (Wills 2008: 12). Dorsal sound increases the monstrosity of the monster: it takes us by surprise, reveals the horror when and where we least expect it. The effect of dorsality can be achieved through the careful 
combination of the elements above. The feeling that the monsters in The Grudge are alive and close by is not only driven by schizophonic technology but also by the dorsal unseen. The otherness of atonality in The Shining and the monstrosity of white noise in The Ring is intensified by their dorsal appearance in these film, out of the blue, unexpected, terrifyingly other. Leitmotifs, as musical signifiers of absent presence, are eminently suitable for the dorsal characterization of monsters, and the shark in Jaws is the paramount example. The first attacks of the shark are accompanied by the well-known motif, and imprint the beast with all the sonic qualities of monstrosity: the chromatic defiance of the semitone represents a musical otherness to smooth tonal melodies, its stubborn repetition exceeds the flow of music, and the low string timbre has dark and ominous overtones. Later on in the film, the same motif occurs before the shark is visible to the diegetic characters, announcing the danger that looms under the surface of the sea as well as that of the screen: here dorsal sound heralds the submerged.

The importance of dorsality for the sonic representation of monstrosity becomes particularly evident when it is replaced by its opposite, obscene monstrosity, which is the hyper-visible, the over-explicit, the often ridiculous representation of monsters. The Hammer movies discussed above illustrate this point. In the overdrive mode of the obscene, monstrous sound no longer meets the functions and qualities set out at the beginning of this article. Obscene sonic monstrosity indicates the life and location of the monsters, but it is no more human than any prefab machine is, and therefore it fails to represent 'our own monstrosity' (Halberstam 1995). Because it is so recognizable, it fails to make the home unhomely and to cause the uncanny return of the repressed. Obscene sonic monstrosity still provides contrast an excessively excessive amount thereof, in fact - but instead of monstrous others it indicates domesticated pet monsters. This very predictable mode of soundtrack composing, therefore, prevents even the possibility of dorsality, as we know exactly when we are going to hear what sound and why. 


\section{Sonic monsters}

Expressions of our worst and best nightmares, monsters need representation - metaphor and mediation - in order to become perceivable. Always 'something of a metaphor providing form for what is formless', Botting argues, monsters

glimmer on boundaries of normalcy, fantasmatic projections of fear and desire, excess and prohibition. [...] Appearing in a form that cannot be recognized, that is, an appearance whose formlessness demands the projection of a form that metaphor provides, monsters remain visible and yet unseen, alien to habits of perception, on the fringes of comprehension. (2003: 345)

The monstrosity of the monster, he argues quoting Derrida, is unfathomable by nature, so that in fact its captivation in representation renders it too familiar, too recognizable already: 'But as soon as one perceives a monster in a monster, one begins to domesticate it, [...] consequently to master whatever could be terrifying in this figure of the monster' (Botting 2003: 345). It is precisely here that sonic monstrosity rears it amorphous head.

Monsters need metaphor. When sound and music communicate monstrosity, they cloak the monster in sonic imagery: blasts of brass, grunts and growls, atonal anxiety. But even though these might reflect monstrous conventions, to what extent do they signify monstrosity? Can sound or music signify anything at all, let alone an unsignifiable Thing like monstrosity? A sonic event in and of itself, after all, defies any referentiality, even that to its own origin; and music, as organized sound, does not and cannot signify anything beyond its own musicality. In the process of the musical event, however, the semblance of signification occurs. Listening experiences always - and involuntarily - generate a crossing-over from the 
absolute non-referentiality of sound per se to the personal meanings inscribed so eagerly in music. Its a priori non-signification enables unlimited inscriptions of meanings: any perceived signified in music is acquired only, generated through countless listening processes. Lawrence Kramer therefore argues that music 'does not mean but precedes meaning' (2002: 279). However, in view of music's phenomenal capacity to override its own acquired meanings - all meaning ascribed to music is unstable, temporary and as changeable as subjectivity itself and replace them with new ones, I would add that music gives simulates meaning at most, and that the very process of simulating meaning destroys the possibility of meaning. Even if music is set out to signify anything, its own recreative phenomenology will interrupt the signifying process, and whatever could have been signified will remain obscured. Monstrous music, accordingly, may suggest a monstrous metaphor but simultaneously escapes it - so that the monster remains uncaptured, evasive, imaginable only, and therefore truly monstrous. With no other signification than that which resonates within us, the sonic monster represents what Julia Kristeva calls 'the I within the Other', the abject: it rings ' $[\mathrm{t}]$ hroughout a night without images but buffeted by black sounds' $(1982: 15,207)$. Simultaneously it is able to represent what Freud calls the uncanny, the Other within the I, the familiar unfamiliar ([1919] 2003: 121-62). ${ }^{3}$ Contextless, this sound returns monstrosity to its core: the ear of the beholder. Because of the involuntary nature of music's un-signifying phenomenology, moreover, its destruction of meaning always takes us by surprise. More dorsally than fear can desire, music returns the monster to its Thingness.

\section{... a strange stillness over everything}

Is monstrosity so noisy at all then? Think of the monster in Mark Z. Danielewski's House of Leaves (2001). We only know it might exist because it growls from time to time. No one ever sees it, and in fact the hollow, ever-expanding corridors of the house itself are so silent that 
even echo remains absent. This monster is all the more monstrous because it does not make any noise. The most uncanny sonic monster hovers in silence - the silence of the House, the silence of the written word. 'Find those pockets without sound. That's where it is' (Danielewski 2001: 26). Sonic monstrosity is dorsality suspended.

\section{Acknowledgements}

This article first appeared in Jørgen Riber Christensen and Steen Christiansen (eds), Monstrologi Frygtens Manifestationer (Aalborg Universitetsforlag, 2013: 127-46). It is reprinted here with kind permission of Aalborg Universitetsforlag.

\section{References}

Baker, R. W. (1970), The Vampire Lovers, London: Hammer.

Barthes, R. (1977), 'The grain of the voice', in Image Music Text, London: Fontana Press, pp. $179-89$.

Botting, F. (2003), 'Metaphors and monsters', Journal for Cultural Research, 7:4, pp. 339-65.

Browning, T. (1931), Dracula, USA: Universal.

Carpenter, J. (1980), The Fog, USA: Debra Hill Productions.

Chion, M. (1994), Audio-Vision: Sound On Screen, New York: Columbia University Press.

Climax Studios (2009), Silent Hill: Shattered Memories, Portsmouth: Climax Studios. 
Danielewski, M. Z. (2001), House of Leaves, London and New York: Doubleday.

Donnelly, K. J. (2005), The Spectre of Sound: Music in Film and Television, London: British Film Institute.

Fisher, T. (1958), Dracula, London: Hammer.

Freud, S. ([1919] 2003), 'The uncanny', in D. McLintock (ed.), Sigmund Freud: The Uncanny, New York: Penguin, pp. 121-62.

Gorbman, C. (1987), Unheard Melodies: Narrative Film Music, Bloomington and Indianapolis: Indiana University Press.

Halberstam, J. (1995), Skin Shows: Gothic Horror and the Technology of Monsters, Durham: Duke University Press.

Hayward, P. (ed.) (2009), Terror Tracks: Music, Sound and Horror Cinema, London: Equinox.

Kramer, L. (2002), Musical Meaning: Toward a Critical History, Berkeley and Los Angeles: University of California Press.

Kristeva, J. (1982), Powers of Horror: An Essay on Abjection, New York: Columbia University Press. 
Kubrick, S. (1980), The Shining, USA: Warner Brothers.

Lerner, N. (ed.) (2010), Music in the Horror Film: Listening to Fear, London: Routledge.

Lost (2004-10, USA: ABC).

Mamoulian, Rouben (1932), Dr Jekyll and Mr Hyde, USA: Paramount.

Murray Schafer, R. (1994), The Soundscape: Our Sonic Environment and the Tuning of the World, Rochester, NY: Destiny.

Murnau, F. (1922), Nosferatu: Eine Symfonie des Grauens, Germany: Prana Film.

Night Shyamalan, M. (1999), The Sixth Sense, USA: Buena Vista.

Rice, A. (2006) Interview with the Vampire. London: Time Warner Books.

Scott, T. (1983), The Hunger, USA: Metro-Goldwyn-Mayer.

Shelley, M. (1985), Frankenstein, Or, The Modern Prometheus, London: Everyman's Library.

Shimizu, T. (2004), The Grudge, USA: Columbia. (2003), Ju-On, Japan: Toei Video Company. 
Stoker, B. (1897/1997), Dracula, New York: Norton.

Torchwood: Children of Earth (2009, UK: BBC 1).

Verbinski, G. (2002), The Ring, USA: DreamWorks.

Whale, J. (1931), Frankenstein, USA: Universal.

Wills, D. (2008), Dorsality: Thinking Back through Technology and Politics, Minneapolis: University of Minnesota Press.

\section{Contributor details}

Isabella van Elferen is Full Professor of Music, Director of Research of the School of Performing and Screen Studies, and Director of the Visconti Studio at Kingston University London, UK. She publishes on film and TV music, video game music, music philosophy, Gothic theory and subcultures, and baroque sacred music. She is the author of Gothic Music: The Sounds of the Uncanny (2012), Mystical Love in the German Baroque: Theology-Poetry - Music (2009), the editor of Nostalgia or Perversion? Gothic Rewriting from the Eighteenth Century until the Present Day (2007), and, with Jeffrey Weinstock, author of Goth Music: From Sound to Subculture (2015). Isabella's Sounds of the Uncanny won the Alan Lloyd Smith prize for best book in Gothic Criticism 2011-13. She is currently working on a monograph on timbre.

Isabella is First Vice-President of the International Association of the Fantastic in the Arts. She is editor for The Soundtrack, member of the advisory board of Horror Studies and 
Aeternum, and was guest editor for Journal for the Fantastic in the Arts (2013), Horror Studies (2016) and Contemporary Music Review (2016). She was a member of the AHRCfunded network Music-based Games, Creativity and Music Education and member of the Advisory Panel of the EC-funded project Europeana Sound led by the British Library.

\section{Contact:}

Kingston University London, 2001 Coombehurst House, Kingston-upon-Thames, KT2 7LB, UK.

E-mail: i.vanelferen@kingston.ac.uk

Notes

\footnotetext{
${ }^{1}$ Intertitle from Nosferatu: Eine Symphonie des Grauens (Murnau, 1922).

${ }^{2}$ As opposed to diegetic music, which originates from a source within the screened narrative and is audible to film, television or game characters also.

${ }^{3}$ I disagree with Kristeva's reading of the relation between the abject and the uncanny here (1982: 5).
} 